\title{
WIND DAMAGE TO TREES IN THE GITAM UNIVERSITY CAMPUS AT VISAKHAPATNAM BY CYCLONE HUDHUD
}

\author{
Mohan Kotamrazu ${ }^{1}$

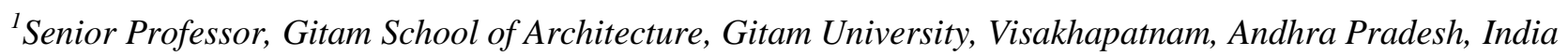

\begin{abstract}
Over the past thirty three years Gandhi Institute of Technology and Management (Gitam University) has evolved into a world class university. The introduction of many exotic and indigenous species of trees and shrubs has transformed the campus into a green oasis. Cyclone Hudhud with wind speeds gusting from 175 to $200 \mathrm{kmph}$ caused massive destruction to the green cover of the campus. Many trees were either uprooted or were severely damaged. A visual assessment of the damage incurred by the trees in the Gitam University campus has been carried out by the author to understand the different ways in which trees respond to cyclonic winds. The results of the study would help in minimizing the damage to trees from future storms.
\end{abstract}

Keywords: Defoliation, salt spray damage, uprooting, bark inclusion.

\section{INTRODUCTION}

Gitam University, spread over an area of approximately 100 acres is located adjacent to the Rushikonda hill along the Visakhapatnam-Bheemunipatnam coastal corridor. Thousands of trees on the campus were either uprooted or sustained serious or partial damage from the extreme winds unleashed by the Very Severe Cyclone Hudhud which struck Visakhapatnam on $12^{\text {th }}$ October, 2014. A post-cyclone damage assessment study has been carried out by the author
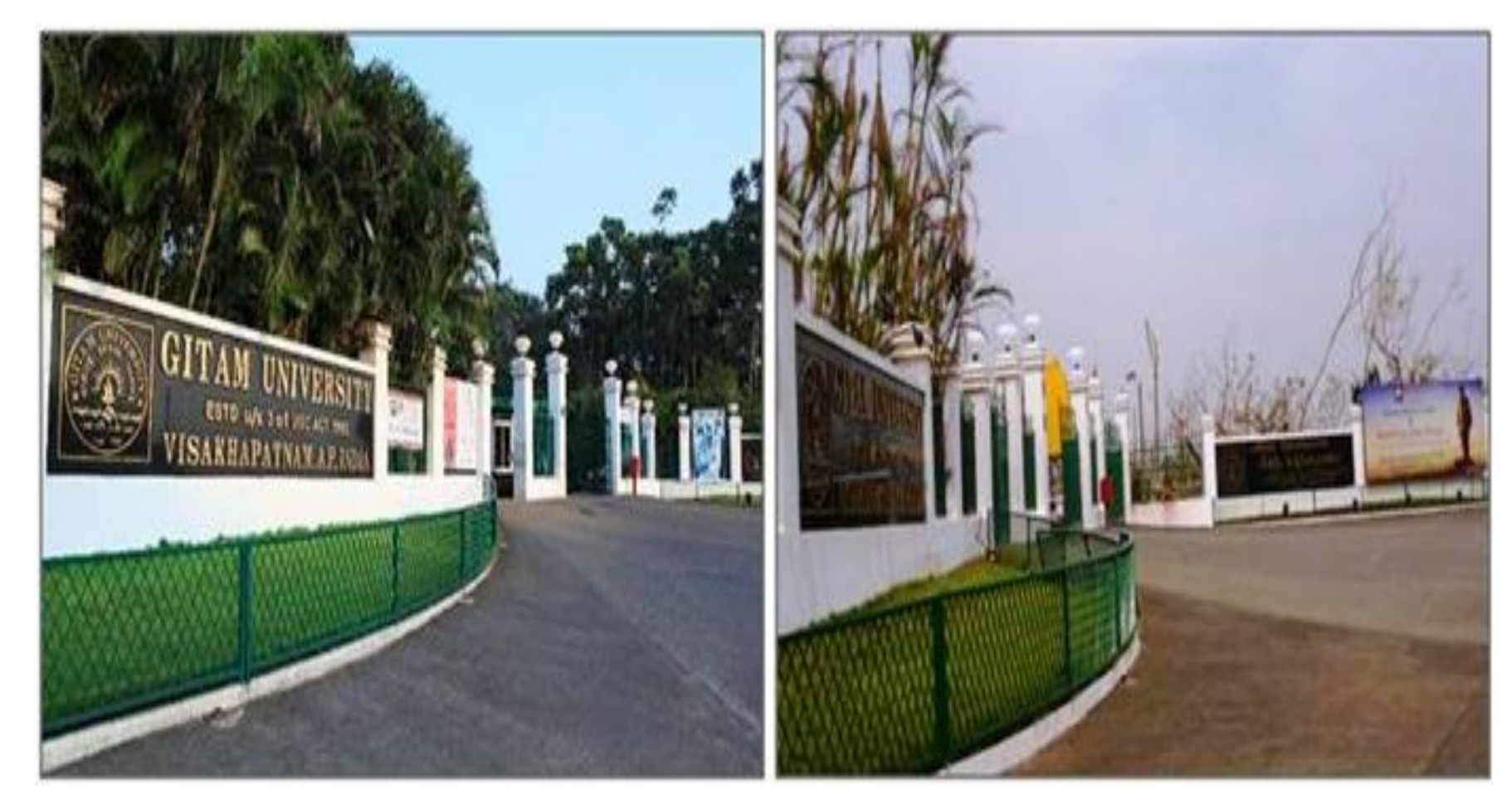

Fig 1 (a) View of Main entrance gate of Gitam University before and (b) after the cyclone. with the objective of studying the impact of cyclonic winds on the trees in the Gitam University campus at Visakhapatnam. Trees that have withstood the storm with minimal damage and trees that are vulnerable to damage from future storms have also been identified. The results of the study would be of use in the selection of wind resistant trees in future plantation programs and in reducing the damage to trees from future storms. 


\section{TYPES OF DAMAGE}

The various ways that the trees in the campus sustained damage are: defoliation, wind throw and uprooting, damage due to twisting of the fronds ( in the case of coconut trees) and stems, snapping of co-dominant branches of trees, and damage from salt spray deposited on the leaves of plants by the cyclonic winds.

\subsection{Defoliation}

Trees like Samanea saman, Ficus religiosa and Azadrachta indica and Spathodea campanulata tend to shed leaves and branches to reduce stress on the stems. The greater the wind speed, the more leaves are shed by trees during a cyclone.
However this does not mean the tree is dead. Trees that have been defoliated by high winds should be saved as most of the plants will refoliate. New leaves are a sign of recovery. Terminalia cattapa, Pongamia glabra and Ficus religiosa trees were the first trees to send out fresh sprouts within two weeks following the cyclone. Trees with broad leaves which do not shed leaves easily under the influence of strong winds, such as Tectona grandis (Teak) and Ficus ariculata(Great Indian Fig) are more vulnerable than small leaved trees. Figure 2(a) shows an Azadrachta indica tree which shed all its leaves and remained intact while Figure 2(b) shows the collapsed Tectona grandis trees which did not lose their leaves even under the influence of strong winds.

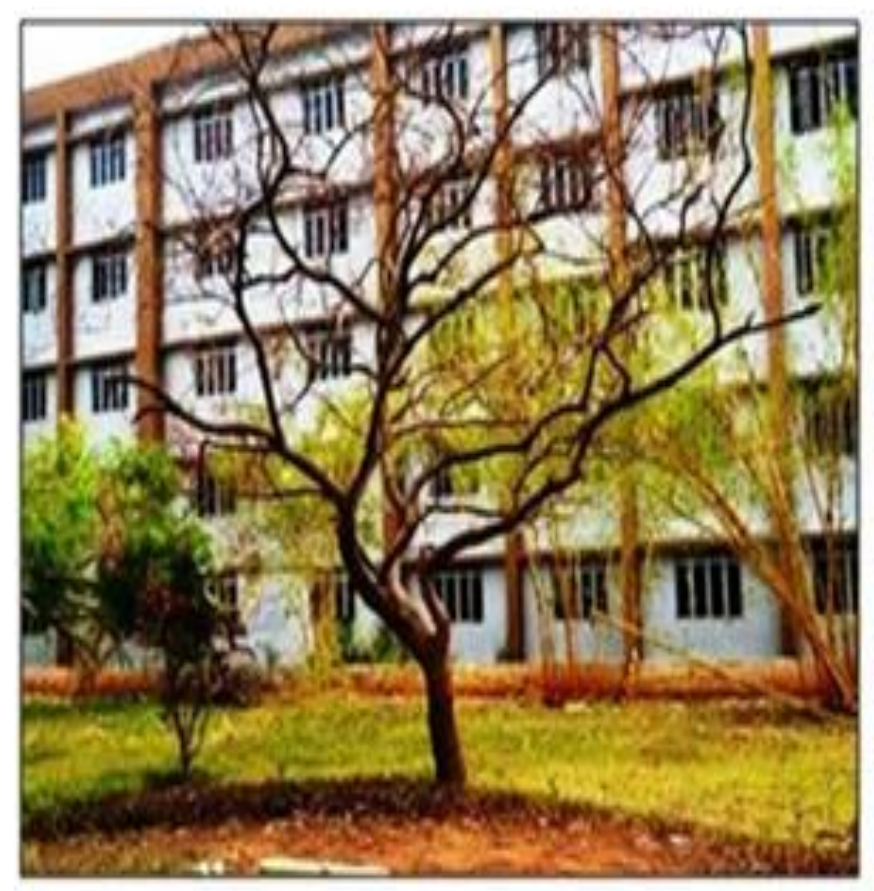

(a)

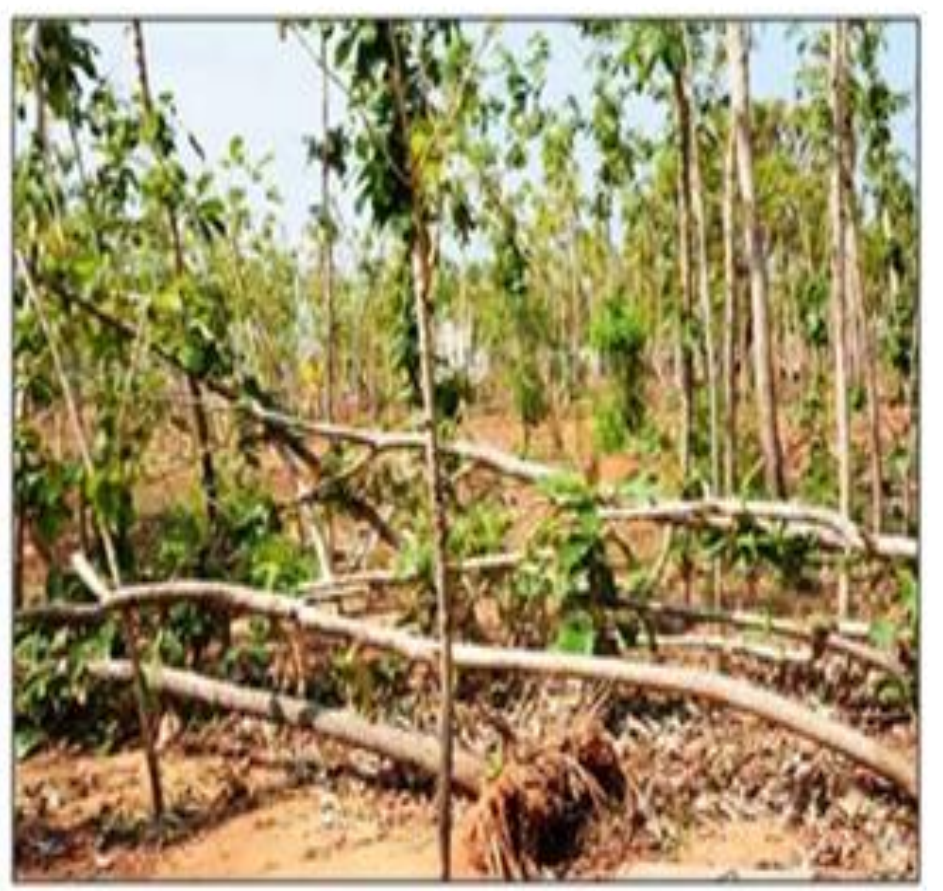

(b)

Fig 2 (a) A defoliated Azadrachta indica (Neem tree) (b) Uprooted Tectona grandis trees which do not shed their broad leaves in the face of extreme winds

\subsection{Salt Spray Damage to Plants}

The aerial drift of salt laden water droplets that are deposited on trees and shrubs causes salt spray damage. When droplets evaporate the salts can penetrate stems, buds and leaves, causing direct damage. Salt spray damage is most frequently seen on seaside plants. Trees and shrubs usually get salt burned on the windward side. An excess of salt in the soil or air will prevent a plant from absorbing water properly and will actually cause the plant to secrete water, a process known as exomosis which leads to dehydration of the plant. All parts of the plant including leaves, stems, roots and fruits may be reduced in size. Leaf necrosis (death), marginal leaf or needle burn, leaf drop and eventual plant death may occur. According to Sinclair (Sinclair, 1987) salt spray damages have been reported on plants $80 \mathrm{~km}$ from the Atlantic Ocean and most of the damage usually occurs within approximately $300 \mathrm{~m}$ of the ocean.
Salt spray damage has been observed in the following species in the university campus: Mimumsops elengi, Tecoma castinifolia, Acacia auriculformis Callophyllum ionophyllum and Polyalthia longifolia trees. Shrubs like Graptophylum pictum showed severe damage while some of the Aralia shrubs have also been badly affected. Trees and shrubs which showed high tolerance to salt spray include Thespesia populnea, Terminalia cattapa, Alstonia scholaris, Nerium oleander and Cassia biflora.

The foliage and branches of trees affected by salt spray should be washed with a stream of water to remove salt, wind and debris and should be watered every third day (Siegendorf, 1984). Mulching prevents evaporation and retains the soil moisture at the root zone of the plant, controls the growth of weeds and subsequent build up of salt in the soil. 


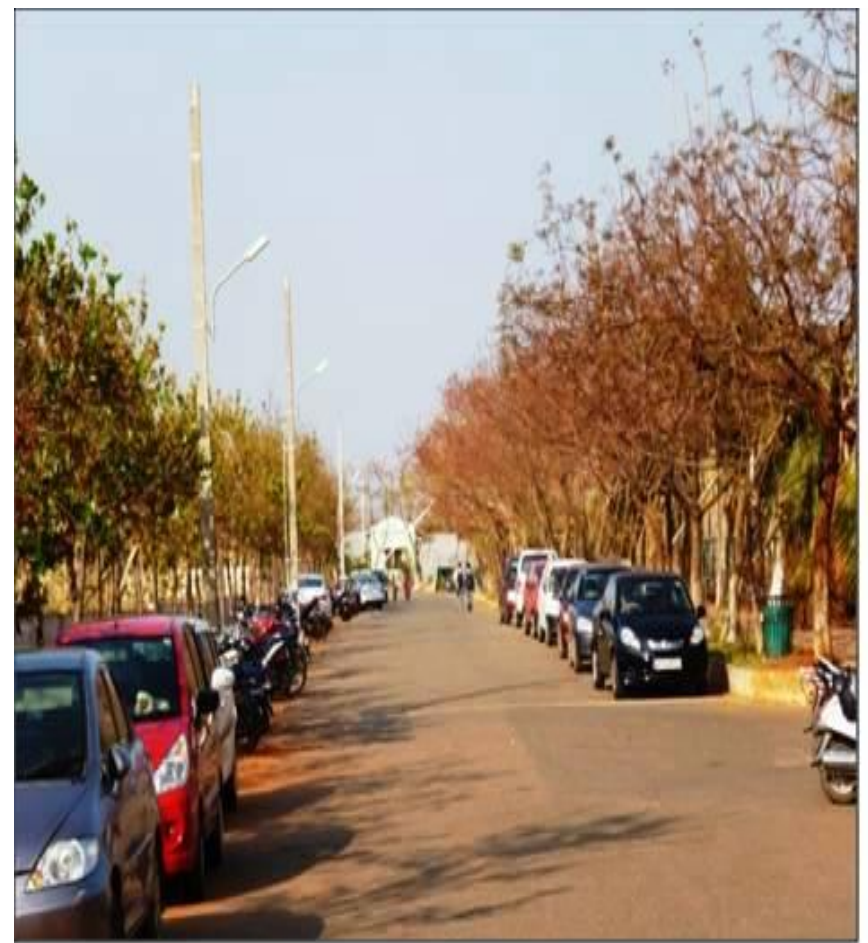

(a)

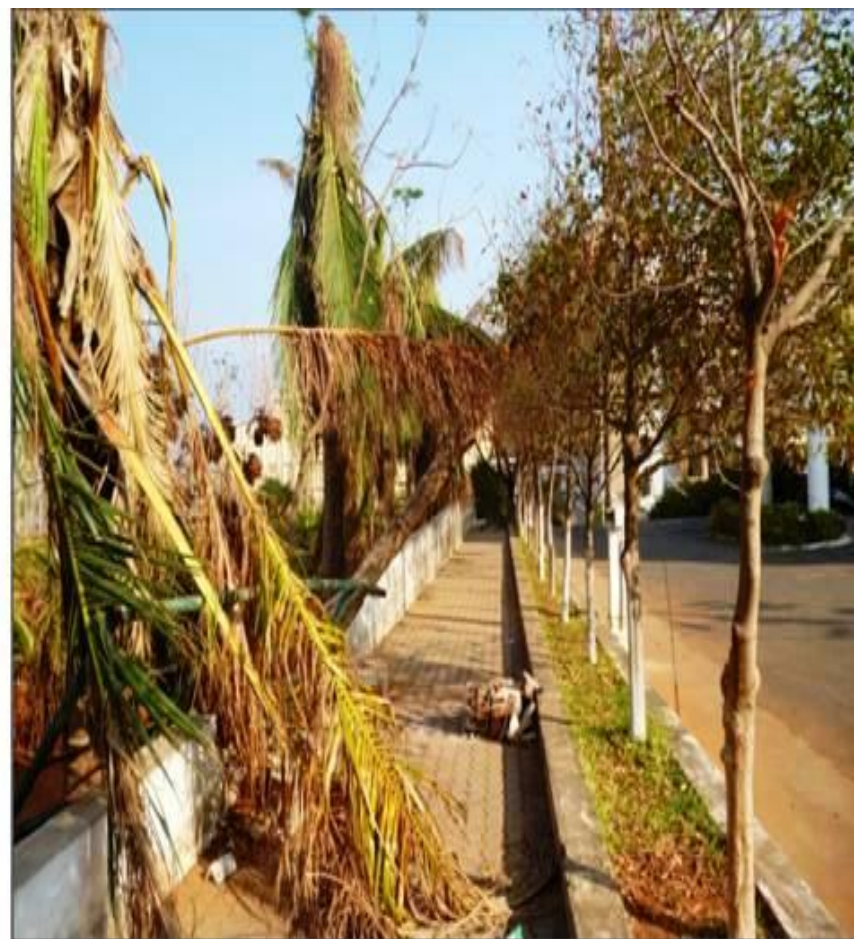

(b)

Fig 3 Discoloration of the leaves of Callophyllum inophyllum ( left) and Tecoma castanifolia and Azadrachta indica trees on the road adjacent to N.T.R. Park (b) Salt burned Mimumsops elengi and coconut trees

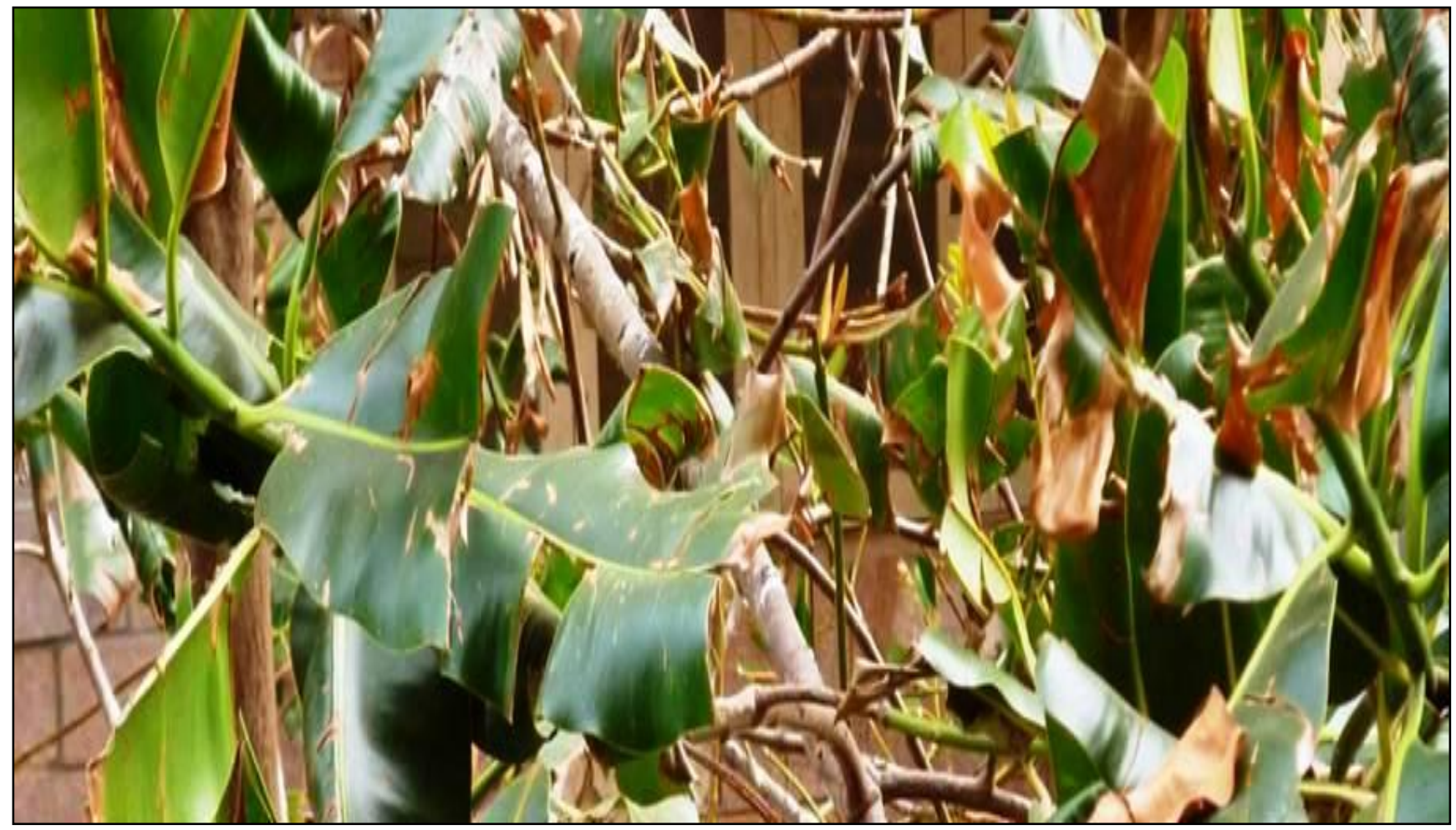

Fig 4 Salt spray damage to the leaves of Callophyllum ionophyllum 

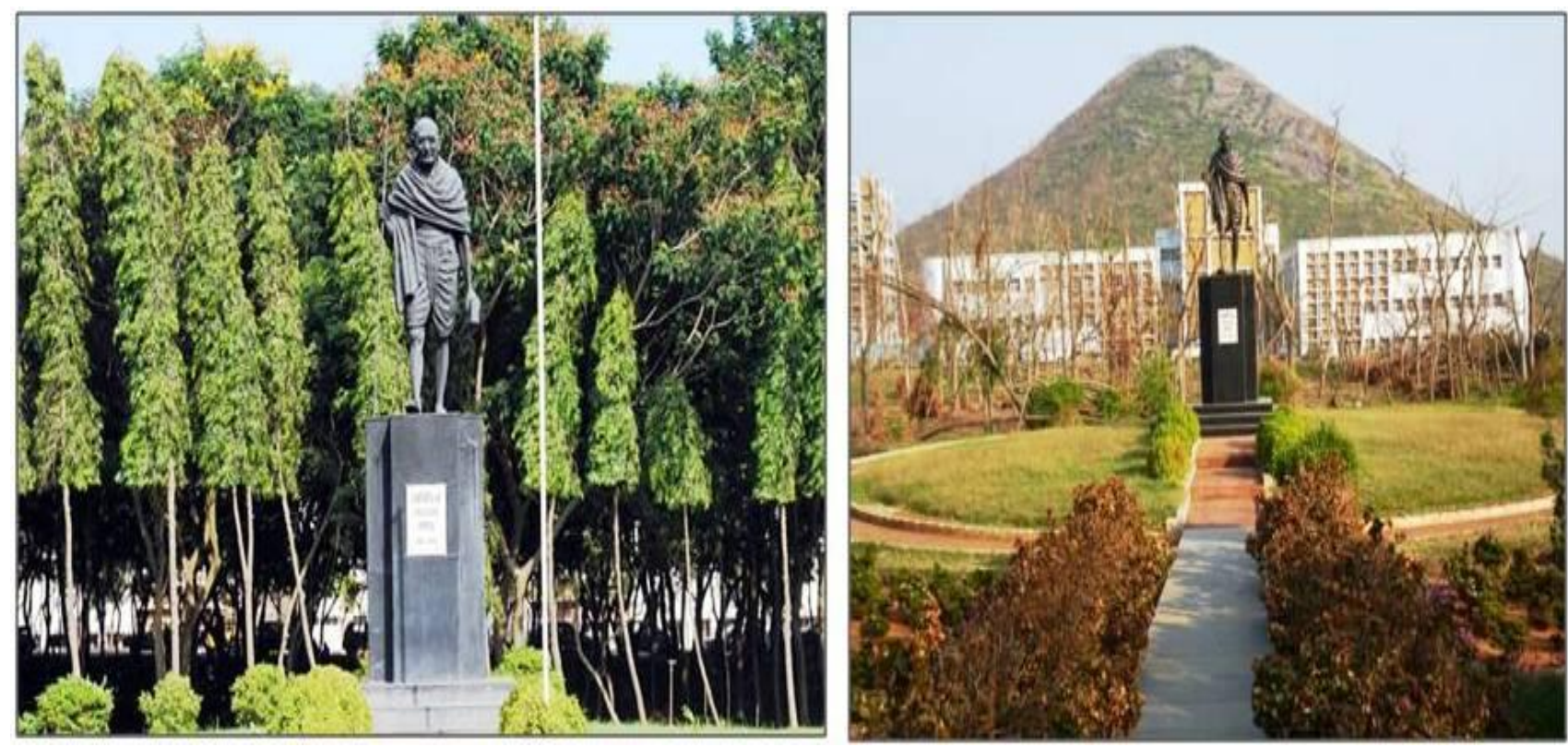

Fig 5 Views of the Gandhi park before and post Hudhud.

The Gandhi Park (Figure 5) at Gitam University was badly damaged by the cyclone. A large number of Polyalthia longifolia and Peltophorum trees were seriously injured. Some of the top heavy Caryota urens palms in this park were fully or partially uprooted.

\subsection{Damage to stems and branches}

Trees and shrubs with branches less than half the trunk diameter have one dominant trunk. A tree with two or more trunks is said to have co-dominant stems or stems of equal size. When the union of the trunk and branch is U-shaped it indicates strong attachment and a V shaped union indicates a weak attachment (Figure 6).

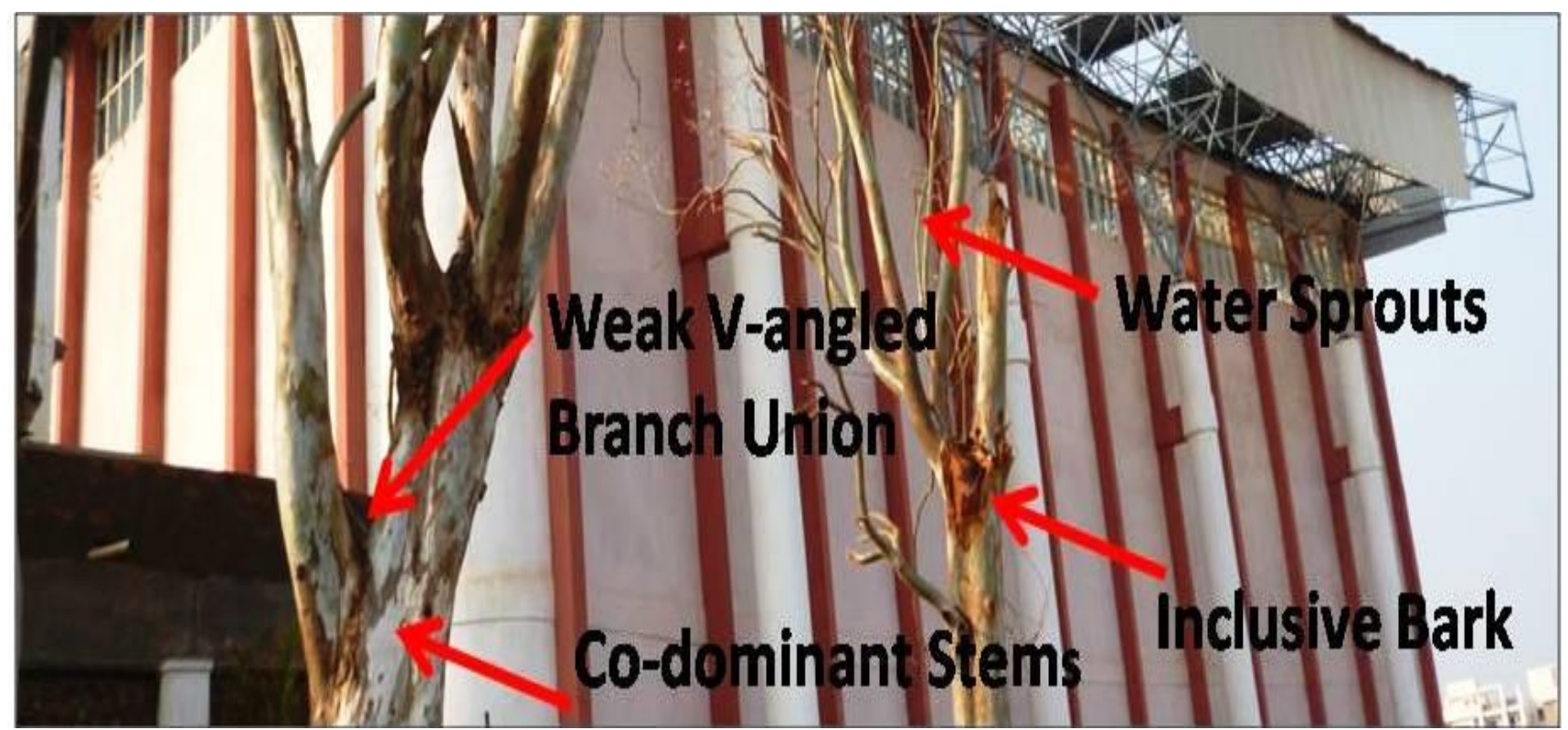

Fig 6 Eucalyptus trees in front of the indoor stadium with loss of canopy and broken branches.

One of the most common locations for the above ground portion of a tree to fail is at the junction of two or more codominant stems. Matheny and Clark (1994) state that codominant stems with included bark do not form connective tissue between stems and are prone to failure. The strength of branch attachments is reduced by the presence of included bark. Kane and Clauston (2008) confirmed that trees with codominant stems are weaker than single stemmed trees through tests on thirty Norway maple (Acer platinodes) trees. Trees with codominant stems failed at $43 \%$ of wood strength while single stemmed trees failed at $79 \%$. Tests on eighty codominant stems removed from the felled trees in the Bartlett tree Research Laboratories in Charlotte, North Carolina showed that codominant stems that have bark trapped in the union are significantly weaker than those that do not have bark included. Figure 6 shows 
damaged Eucalyptus trees in front of the Indoor Sports Complex in the Gitam University. Codominant stems with a weak $\mathrm{V}$ angled branch union with bark inclusions make these trees highly vulnerable to wind damage. Upright water sprouts (Epicormic shoots) or suckers, which are weakly attached, emerge from the damaged portions of the codominant stems. These Epicormic sprouts should be pruned as they usually break off in strong winds

Tall trees with a single tapering stem, layered branches that allow the wind to pass through and deep roots such as Araucaria heteryphylla suffered minimal damage from extreme winds as seen in Figure 7a.

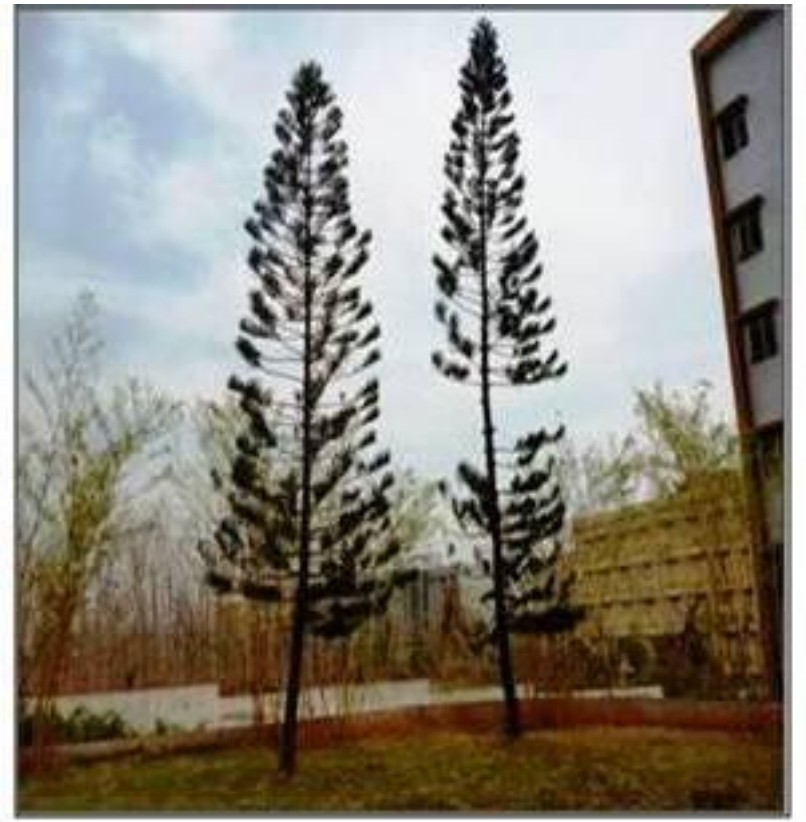

(a)

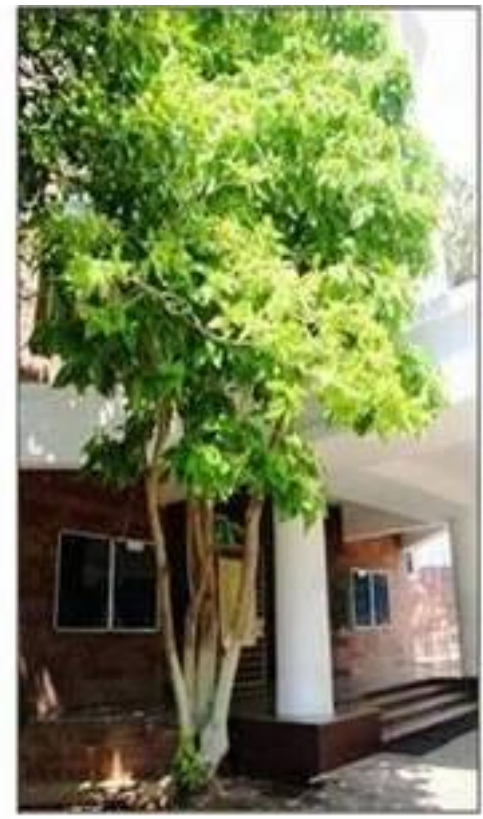

(b)

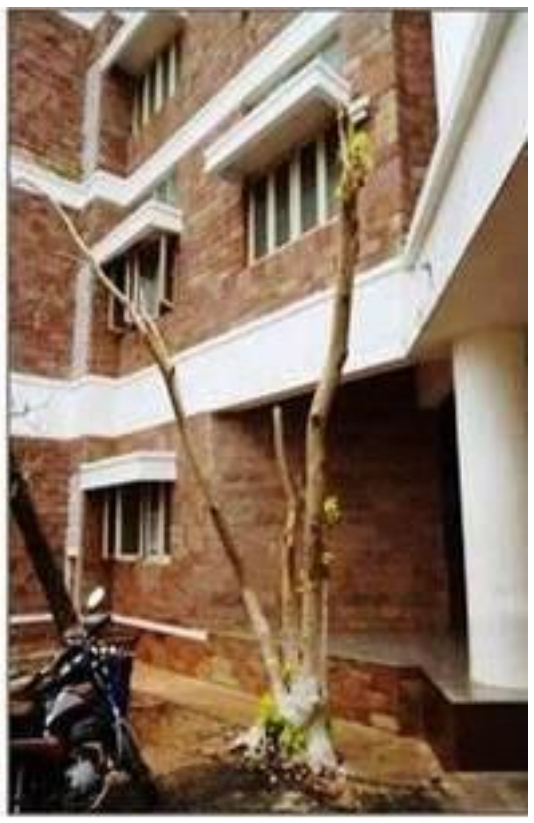

(c)

Fig 7 (a) Two single stemmed Arcauria heterophylla trees with golden bamboo trees in the rear. (b) A Pisonia alba tree in front of the Visveswarraya Bhawan Gitam (c) Pisonia alba tree with multiple codominant stems and entire canopy removed by cyclonic winds.

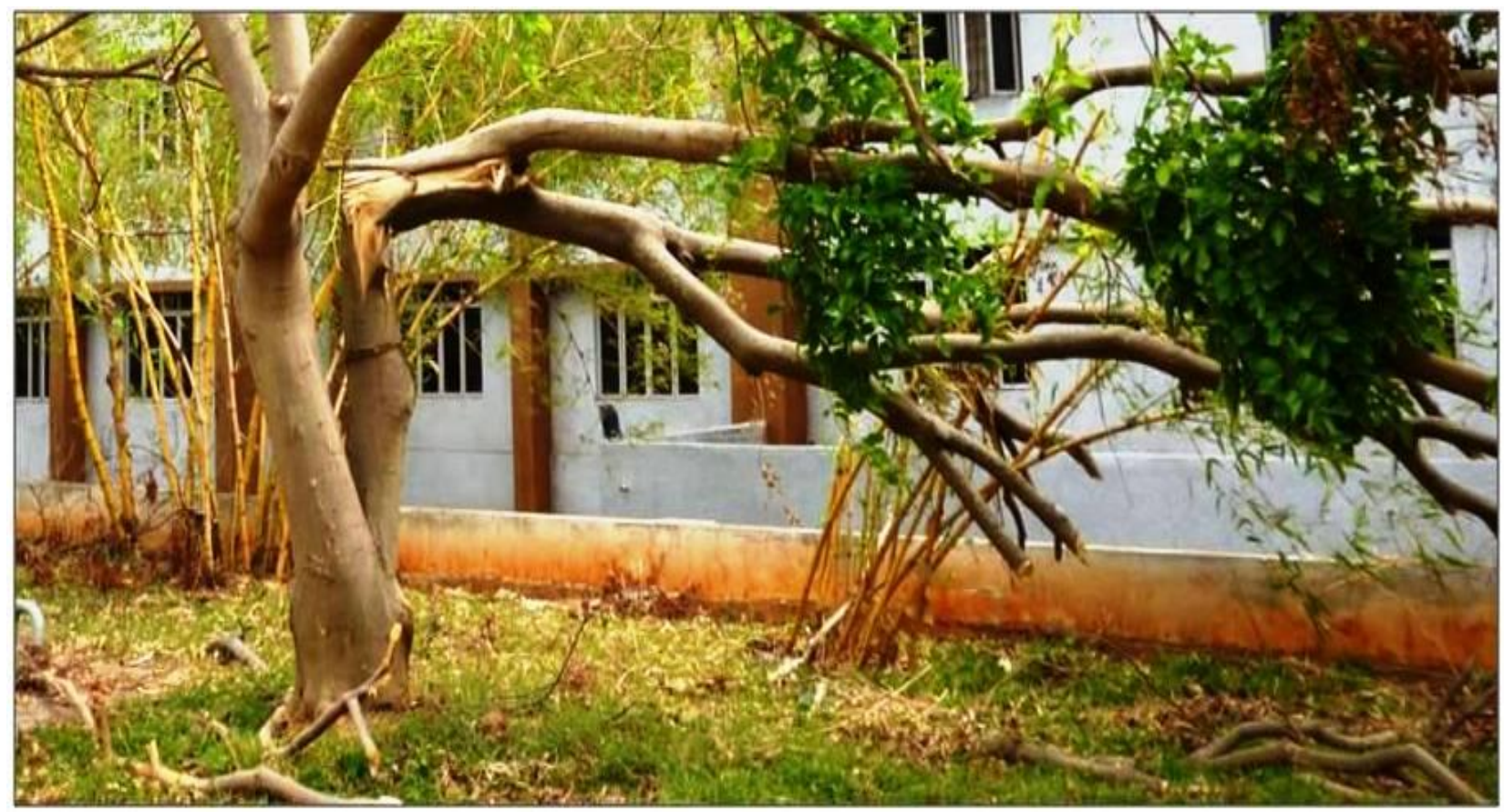

Fig 8 Splitting of a codominant stem of a mature Pongamia pinnata tree. 
A Pongamia pinnata tree located behind the Vishveshwaraya Bhawan whose codominant stem snapped from excessive winds is shown in Figure 8. The crack in the broken stem extends well into the trunk. The upper part of the codominant trunk again has further codominant stems. Inclusion bark is seen in between the union of the codominant stems. The crack in the main codominant stem will not heal and the remaining stem is likely to fail.Most of the fast growing Peltophorum trees in the Gitam campus, which have shallow roots and brittle codominant stems suffered from broken limbs and stems.
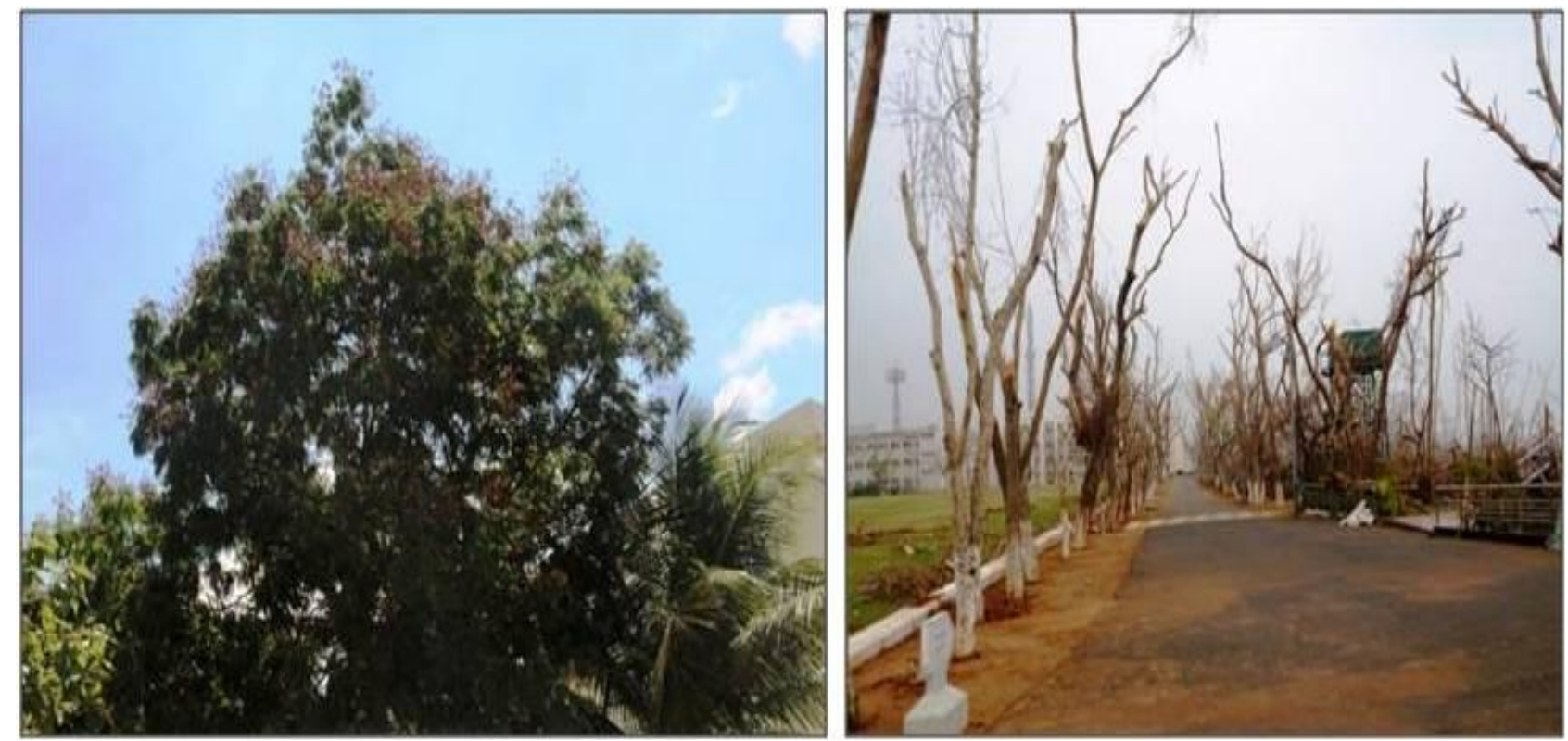

Fig 9 (a) Foliage of Peltophorum pterocarpum. (b) All the Peltophorum trees either lost their foliage or their branches during the cyclone.

The impact of the passage of the eye of the cyclone is seen from the damage to the fronds of the cocos nucifera (coconut) trees in the N.T.R. Park. An eye passage brings with it rapid changes in wind direction, which imposes torques and can twist the vegetation or even structures. As seen in Figure 10(a), the coconut fronds which were weakened by the winds from one direction have been subsequently severely damaged when hit upon by the strong winds from the opposite direction. A similar type of damage (twisting of the stem) to the Sweitenia mahagoni ( Mahagony) tree at N.T.R. Park is seen in Figure 10(b).

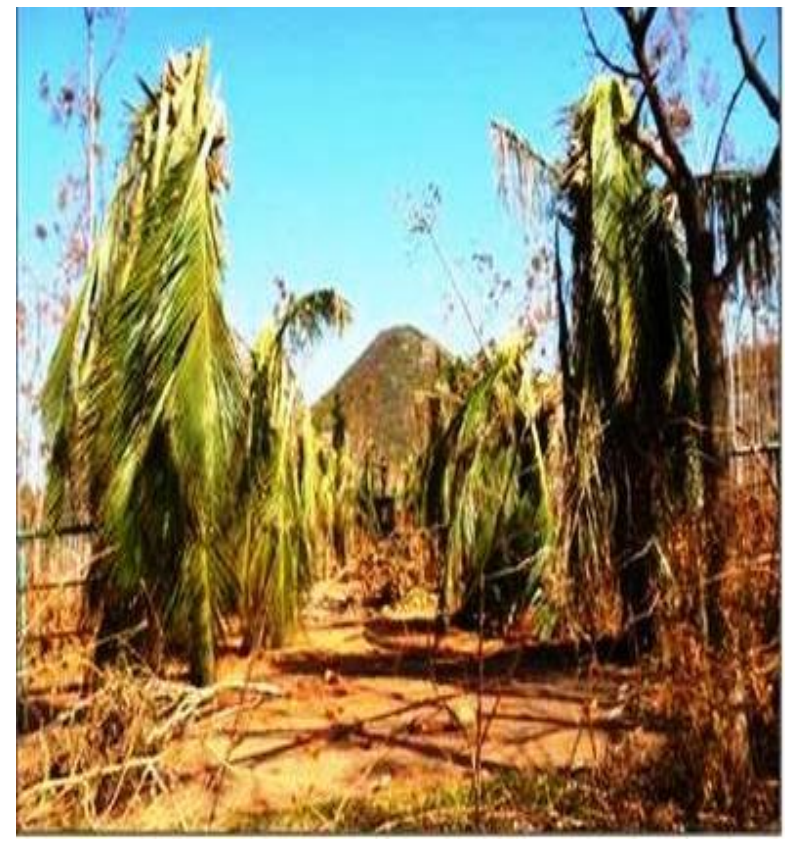

(a)

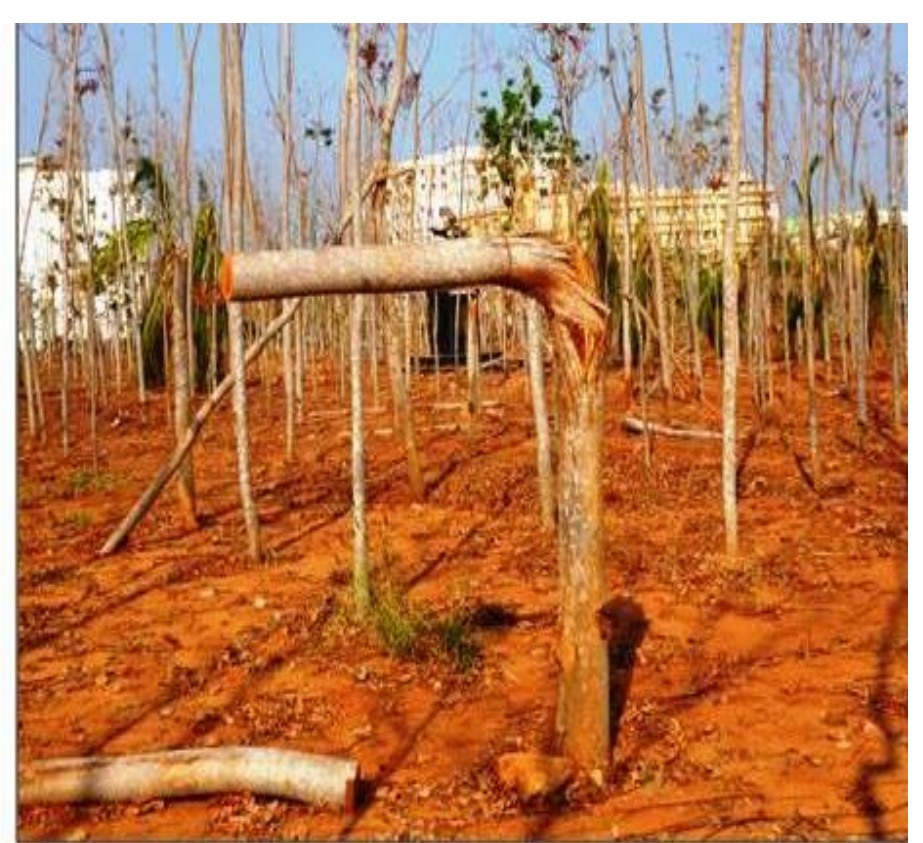

(b)

Fig 10 (a) Damaged coconut palm fronds in N.T.R. park (b) Twisted stem of a Sweitenia mahagoni ( Mahagony) tree in N.T.R. Park. 


\subsection{Windthrow and Uprooting of Trees}

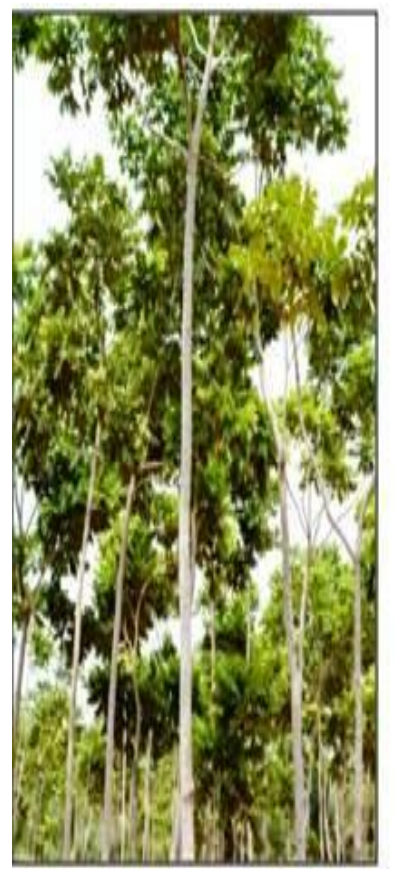

(a)

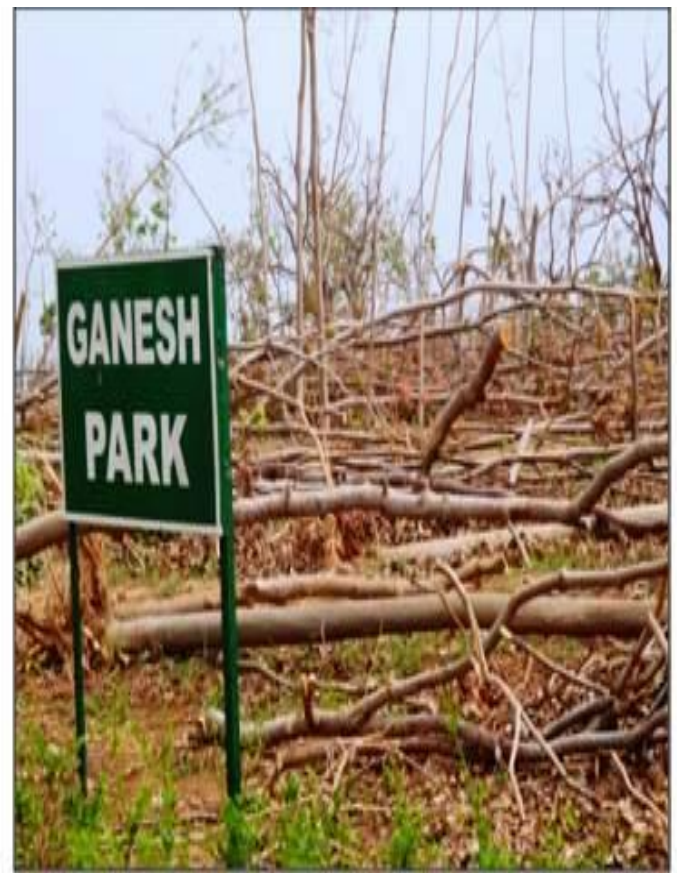

(b)

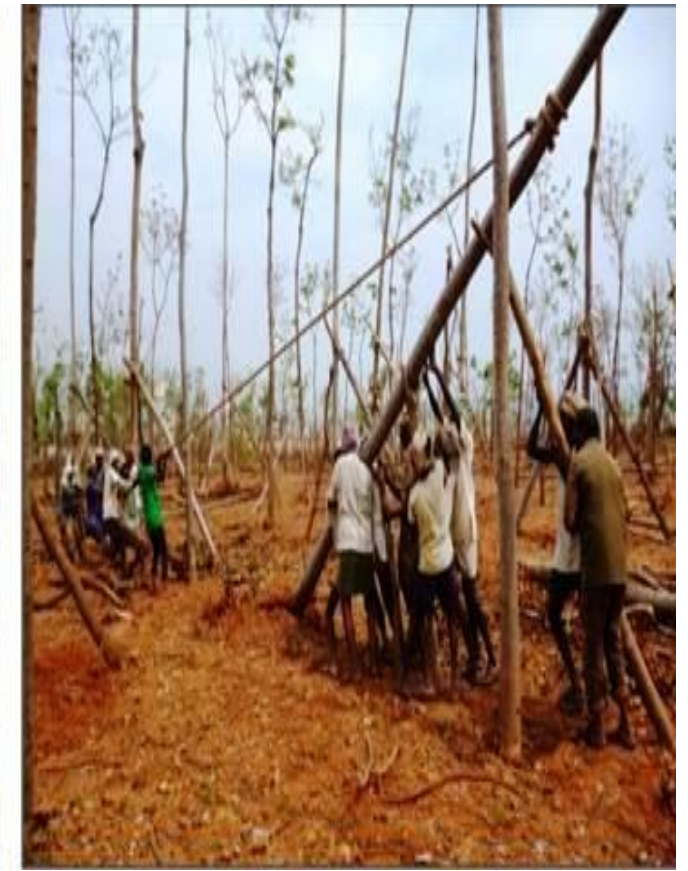

(c)

Fig 11 View of the Sweitenia mahagoni trees before the storm (b) Uprooted Sweitena mahagoni trees in Ganesh Park at Gitam University. (c) A Sweitenia mahagoni tree being restored.

In the face of extreme winds tree are likely to uproot, break or lean. Wind resistance is the ability or capacity of trees to survive ( remain standing and living) in the face of extreme winds. A tree's height is an important factor in wind damage. Taller trees are more vulnerable to breakin or uprooting. Tall trees with deep roots, wide spaced branches and a symmetrical, tapering crown such as Araucaria heterophylla have fared well in the cylone while the tall, top heavy Mahagony trees with very little taper and shallow roots sustained severe injuries. Figure 11(a) shows the Mahagony trees prior to the storm. Uprooted Mahagony trees at N.T.R. Park are seen in Figure 11(b). Many Mahagony trees have been restored in Ganesh Park as well as N.T.R. park. Mahagony trees however are good compartmentalizers, i.e. they are quick to recover from wounds. Figure 11(c) shows a Mahagony tree being restored in Ganesh park.Damage to Mahagony trees has been considerbaly less since they have been planted in groups. The greatest measure for reducing breakage and windthrow of trees involves pruning. The concept is to reduce the surface area of a tree, allowing more wind to pass through (Siegendorf, 1984).

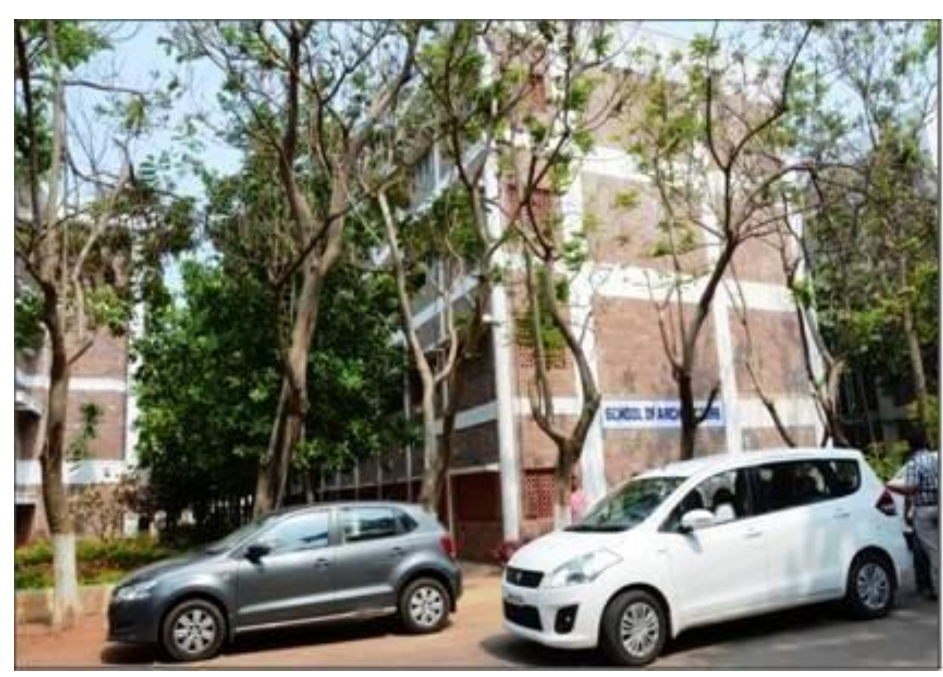

(a)

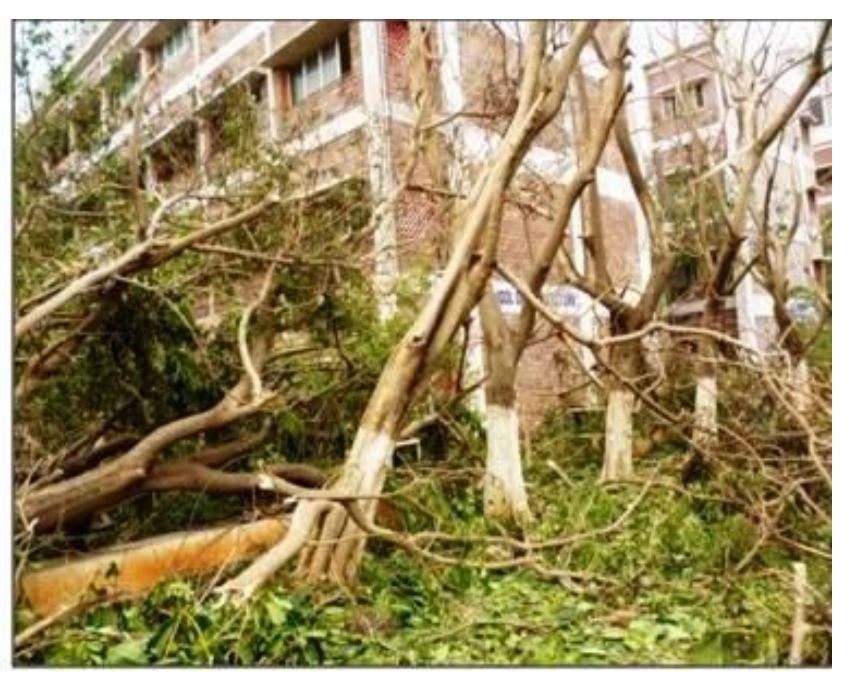

(b)

Fig 12 (a) Row of Spathodea campanulata trees in front of the School of Architecture before the cyclone. (b) Uprooted and damaged Spathodea campanulata blocking the entrance to the Architecture building after the cyclone. 
View of the Spathodea campanulata trees in front of the School of Architecture building a few months before the cyclone is shown in Figure 12.(a) and Figure 12.(b) shows the uprooted and partially collapsed Spathodea trees in the aftermath of the cyclone.

Spathodea campanulata, an evergreen tree, native to the tropical forests of Africa bears spectacular organge coloured flowers when in bloom. A study conducted by the author identified the various types of birds that visit this tree during different seasons. Mynas visit this tree for nectar during the flowering period (Figure 13a). Thereafter parrots visit this tree and feed on the fluffy seeds of the tree, followed by squirrels once the seeds are opened by the parrots. However this exotic tree (a native of Africa) has several drawbacks which make it vulnerable to strong winds. It has shallow exposed roots which get damaged when planted adjacent to roads and pavements. Further it has a number of codominant stems with bark inclusions and a soft trunk that is susceptible to wind throw. Figure13(c) shows the Spathodea tree which got uprooted under the influence of extreme cyclonic winds.

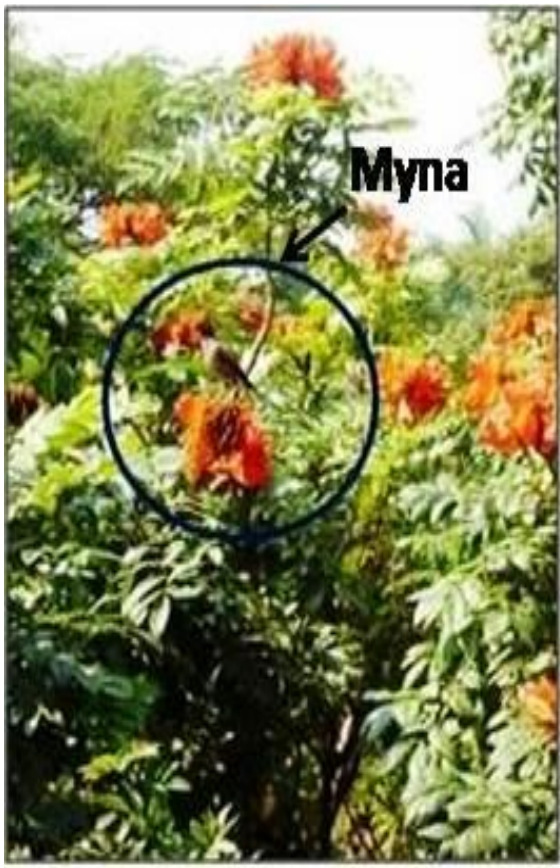

(a)

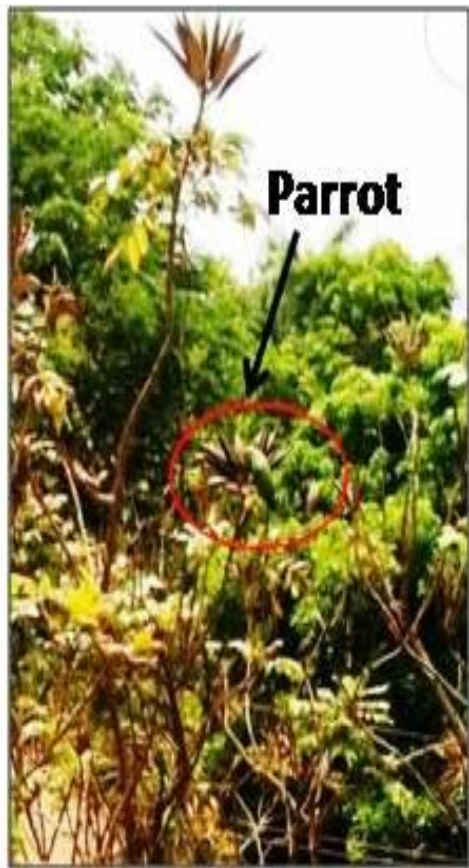

(b)

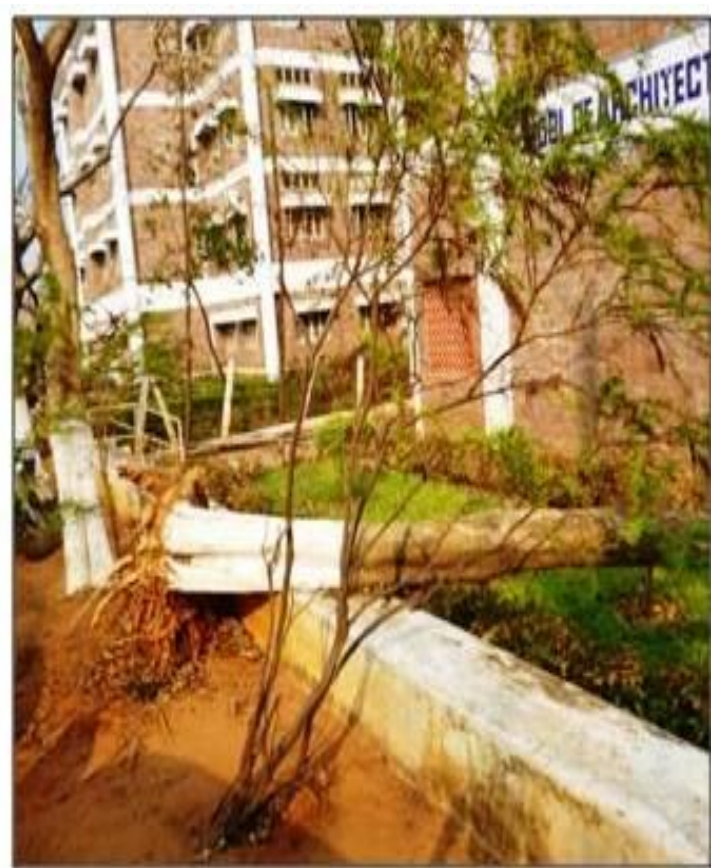

(c)

Fig 13 (a) Myna bird on the flower of Spathodea campanulata (b) Parrot opening the seed of Spathodea campanulata (c) The uprooted Spathodea campanulata tree

\subsection{Leaning Trees}

The major roots of leaning trees are usually broken, which makes them unsafe. Since major roots are severed medium aged and matured leaning trees should not be righted as they are usually unstable and unsafe. If a leaning tree is likely to fall on a person, building, power line or a roadway, it should be removed. Figure 14(a) shows a Spathodea tree leaning on an adjacent tree and Figure 14(b) shows the severed roots of this tree. Figure14(c) shows epicormic shoots or suckers that have emerged from the points along the stem where a codominant stem had broken earlier. Epicormic sprouts are not firmly embedded in the stem and are very susceptible to wind damage. Figure 15(a) shows several fallen and leaning Mahagony trees from the Gandhi Park. Figure 15(b) shows a leaning Caryota urens (Fish Tail Palm) palm from the same park. Most of the fish tailed palms fared very badly during the cyclone. 


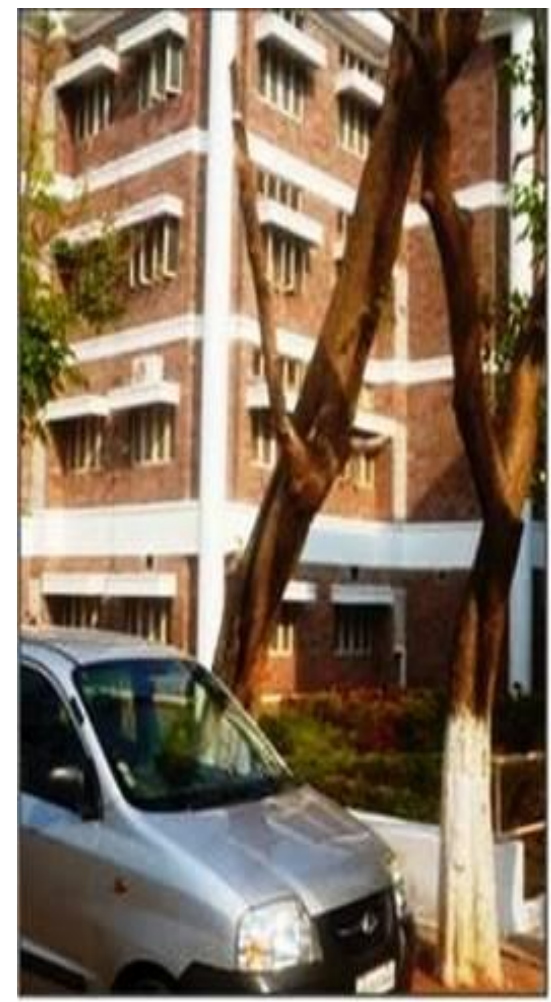

(a)

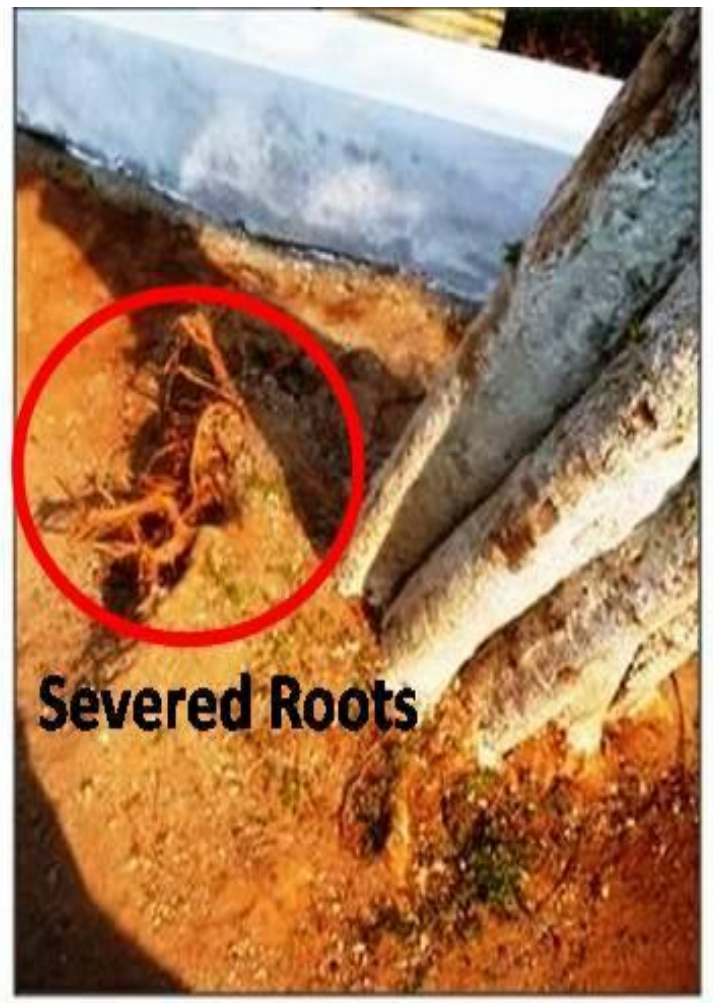

(b)

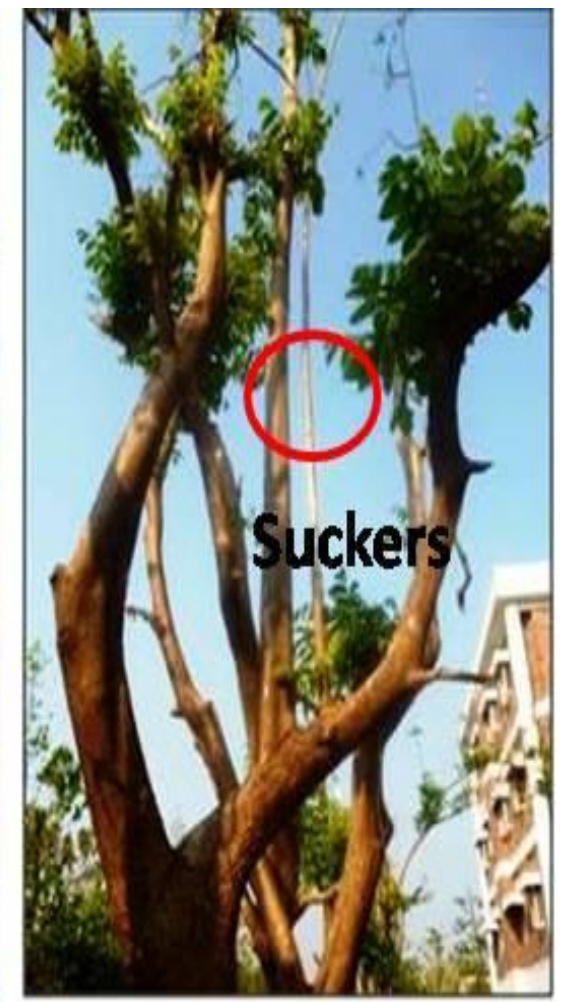

(c)

Fig 14 (a) A damaged Spathodea campanulata tree leaning on another adjacent tree. (b) Severed roots of the Spathodea tree. (c) Vertical Epicormic stems or suckers on a codominant stem of the Spathodea tree.

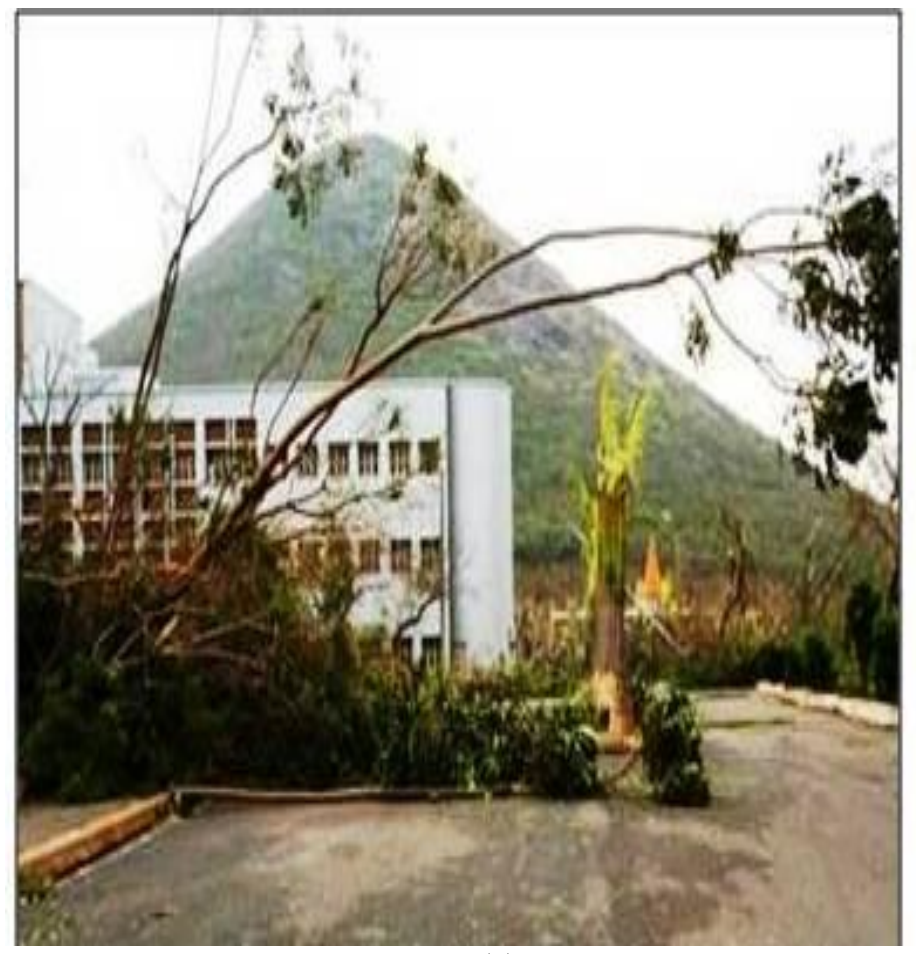

(a)

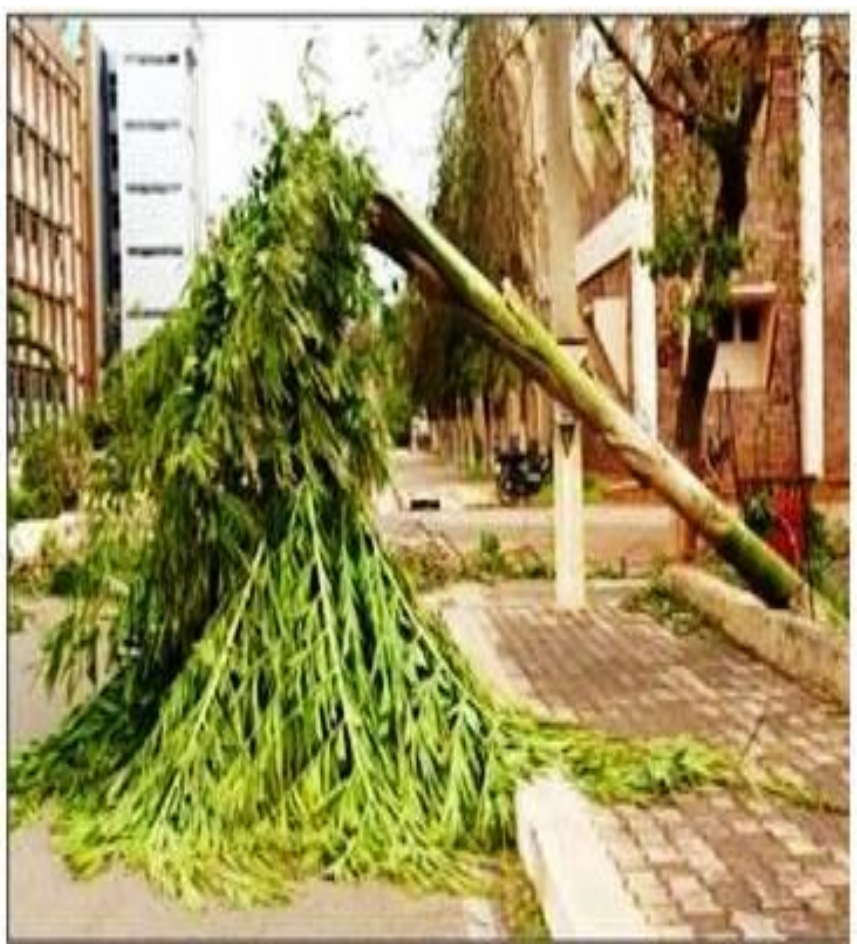

(b)

Fig 15. (a) Uprooted and leaning Mahagony trees in Gandhi Park. (b) A leaning Caryota urens ( Fish-tailed Palm) with roots damaged in Gandhi Park. 


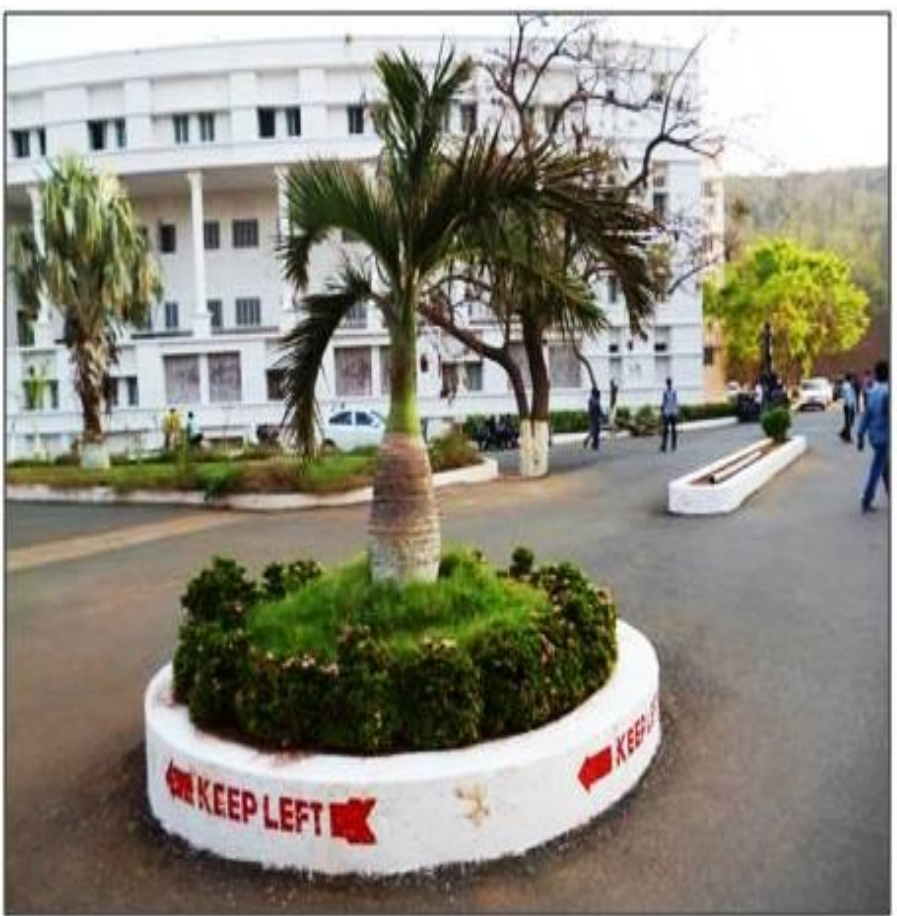

(a)

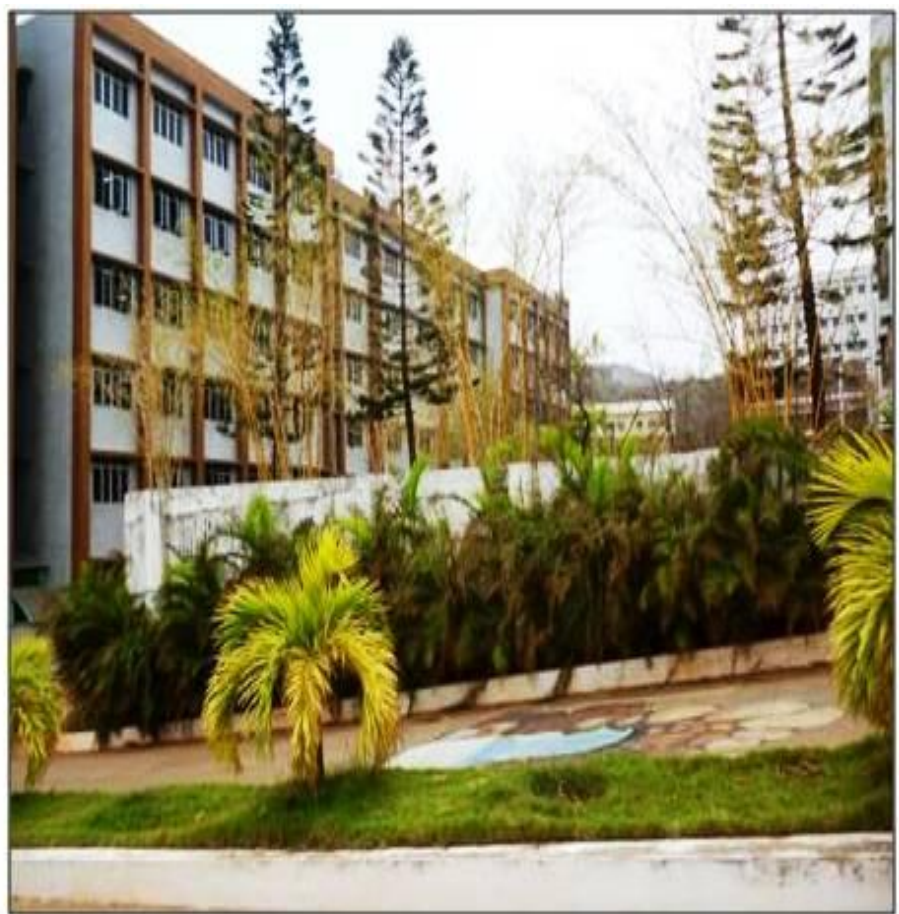

(b)

Fig 16 (a) The aerodynamic stem and leaves of the bottle palm make it highly wind resistant. (b) Veitchia merrielli gold, Areca catechu, Arcauria heterophylla and Bambusa vulgaris trees survived the storm with minimal damage.

Some of the trees that survived the storm with little or minimal damage are shown in figure 16. Studies of storm damaged trees by the author in various parks in the city have shown that the trees that fared well in the Gitam Campus also did well in the above mentioned parks. Densely planted bamboo groves performed very well when compared to trees planted in isolation. The multistemmed Areca palms in the Gitam campus also showed good wind resistance. Some of the exotic varieties of Palms which have stood up to the fury of the storm are: Veitchia merreli gold (Christmas Palm) a native of Phillipines and Hyphorbe lagenicaulis (Bottle Palm) a native of Mauritius, which showed good wind resistance and salt tolerance. The exotic trees which got completely uprooted include: Spathodea campanulata ( Native of Africa), Greviella robusta ( Silky Oak) and Callistemon lanceolatus ( Bottle Brush), both natives of Australia and Sweitenia Mahagoni (Native of Florida and the Carribean). The type of damage incurred by different trees and palms are summarised in Table1.

Table 1 Type of Damage Sustained by Trees and Palms at Gitam University

\begin{tabular}{|l|l|}
\hline Scientific Name & Type of damage/Comments \\
\hline Spathodea campanulata & Trees uprooted, total defoliation and breakage of stems. \\
\hline Bauhinea variegata & Uprooted, prone to salt spray damage and splitting. \\
\hline Peltophorum pteracarpum & Extensive damage to co-dominant stems, uprooting. \\
\hline Callophyllum ionophyllum & Single stemmed,wind resistant. Damage by salt spray. \\
\hline Pongamia pinnata & Mature trees prone to breakage of codominant stems. \\
\hline Delonix regia & Brittle bark. Susceptible to loss of canopy and stems. \\
\hline Dalbergia sisoo & Brittle bark, easily uprooted. \\
\hline Tecoma castanifolia & Not salt spray resistant but quick to recover \\
\hline Sweitenia mahagoni & Shallow roots, top heavy crown, easily uprooted. \\
\hline Mimumsops elengi & Wind resistant but susceptible to to salt spray damage \\
\hline Terminalia catappa & Highly wind resistant, very fast recovery after cyclone \\
\hline Greviella robusta & Slender, top heavy. Prone to uprooting and defoliation \\
\hline Tectona grandis & Younger species survived. Mature trees got uprooted \\
\hline Eucalyptus spp. & Easily uprooted. Dangerous if adjacent to buildings \\
\hline Azadrachta indica & Defoliation without branch breakage. Quick to recover \\
\hline Bambusa vulgaris & Very stable when planted in groups. Wind resistant \\
\hline Ficus benjamina & Vulnerable to salt spray damage. Wind resistant \\
\hline Acacia auriculformis & Easily uprooted, brittle stems. Not wind resistant \\
\hline Polyalthia longifolia & Leaves susceptible to salt burn. Damaged but standing \\
\hline
\end{tabular}




\begin{tabular}{|l|l|}
\hline Nerium oleander & High resistance to wind and salt spray tolerance \\
\hline Cassia biflora & High resistance to wind and salt spray damage \\
\hline Araucaria heterophylla & Pyramidal symmetrical form. Wind and salt resistant \\
\hline Caryota urens & Top heavy. Highly vulnerable to wind loading. \\
\hline Pisonia alba & Multiple codominant stems that are break easily \\
\hline Hyphorbe lagenicaulis & Aerodynamic form. Minimal damage from wind or salt. \\
\hline Bismarck nobilis & Top Heavy. Moderately damaged but still standing \\
\hline Areca catechu & Wind resistant but showed moderate salt spray damage \\
\hline Veitchia merelli & Highly resistant to damage from wind and salt spray \\
\hline Cocos nucifera & Top heavy. Fronds damaged but standing \\
\hline
\end{tabular}

\section{CONCLUSION}

The information that we have today regarding the way trees respond to natural disasters comes from post-damage studies. Post- damage assessment of the trees at Gitam University has provided valuable information about how, when and why trees fail in storms. This information coupled with a structural pruning management program will go a long way in reducing the losses to the trees in the Gitam University campus at Visakhapatnam from future cyclonic storms.

\section{REFERENCES}

[1] Kane,B and Clouston,P.( 2008)Tree pulling tests of large shade trees in the genus Acer, Arboriculture and Urban Forestry 34(2), pp. 101-109.

[2] Matheny,N.P. and Clark, J.R.( 1994) A Photographic Guide to the Evaluation of Hazard Trees in Urban Areas, International Society of Aboriculture, Champaign, IL pp. 85.

[3] Siegendorf.L. (1984) Hurricane Tree Care, Journal of Aboriculture, 10, pp. 217-221.

[4] Sinclair,W.A, H.H.Lyon and W.T. Johnson. (1987) Diseases of Trees and Shrubs, Cornell University Press Ithaca, NY, pp. 575.

[5] Smiley,E.T.(2003) Does included bark reduce the strength of co-dominant stems? Journal of Aboriculture,29(2), pp.104-106. 